\title{
Effect of Silver Nanoparticles On Energy Metabolism In Selected Tissues Of Aeromonas Hydrophila Infected Indian Major Carp, Catla Catla
}

\author{
${ }^{1,}$ T. Kiran Reddy, ${ }^{2,}$ S. Janardana Reddy And ${ }^{3,}$ T.N.V.K.V. Prasad \\ ${ }^{I}$ Divison of Aquaculture Biotechnology, Department of Fishery Science and Aquaculture, \\ Sri Venkateswara University, Tirupati-517 502, AP, INDIA \\ ${ }^{2}$ Department of Soil Sciences, Sri Venkateswara Agricultural College, \\ Tirupati-517 502, AP, INDIA
}

\begin{abstract}
The aim of the present study was to evaluate the effect of silver nanoparticles (AgNPs) on energy metabolic enzymes in selected tissues of Aeromonas hydrophila injected Indian major carp, Catla catla. Fishes exposed to $1 / 10^{\text {th }}$ concentration of AgNPs $(100 \mu \mathrm{g} / \mathrm{l})$ did not alter lipid peroxidation levels as compared to $1 / 5^{\text {th }}$ concentration of AgNPs in gills, liver and kidney of fishes. Therefore, $1 / 10^{\text {th }}$ concentration of AgNPs was selected for subsequent experiments. Significant decrease in the activity levels of succinate dehydrogenase with a significant increase in the activity levels of glucose-6-phosphate dehydrogenase and lactate dehydrogenase in gills, liver and kidney of A. hydrophila infested fishes as compared to controls over a 14-day exposure period. On the other hand, exposure of bacterial infected fishes to $1 / 10^{\text {th }}$ concentration of AgNPs reversed the activity levels of enzymes in selected tissues as compared to bacterial infected fishes. However, no significant changes were observed in the activity levels of selected enzymes in tissues of fishes exposed to $1 / 10^{\text {th }}$ concentration of AgNPs alone over controls. From the results, it can be concluded that A. hydrophila injection leads to prevalence of anaerobic conditions to meet the demand of energy in tissues whereas AgNPs through their antibacterial properties mitigate A. hydrophila induced changes in oxidative metabolism thereby energy crisis in tissues of fishes.
\end{abstract}

Key Words- A. hydrophila, Catla catla, lipid peroxidation, oxidative enzymes, silver nanoparticles

\section{Introduction}

Aquaculture is gaining importance day-by-day as one of the food production sectors in addition to terrestrial sources to meet the needs of food problem for ever growing population (1). It is well known that among the indigenous fish fauna, Indian major carp, Catla catla is one of the commercially and highly cultivable species among aquaculture species (2). However, bacterial infections are the major constraint for rapid cultivation of these species and moreover, it is believed that contaminated water is one of the root causes for the origin of bacterial-borne infections in fishes (3). Aeromonas hydrophila is a gram negative opportunistic pathogen that commonly infects freshwater fishes (4). In fishes, it causes a disease known as hemorrhagic septicemia where lesions occur within numerous organs and finally leads to ulcers of the fish's skin (5). In $C$. catla, infestation of $A$. hydrophila adversely targets immune system of fishes $(6,7)$. In addition, previously it has been reported that it negatively affects spleen, which play an important role fish immune responses $(8,9)$. Earlier it has also been suggested that A. hydrophila accumulates in vital organs such as liver and kidney of freshwater fishes including C. catla (4). Thus, it seems apparent that A. hydrophila negatively targets all vital organs of the fish and eventually leads to death. Furthermore, A. hydrophila has ability to cause zoonotic diseases where mismanagement of these bacteria might even affects humans through fishes. Though, antimicrobial agents such as terramycin and Remet-30 are currently available against $A$. hydrophila infection, the wide and frequent use of these antibiotics in fisheries has resulted in development and spread of antibiotic resistance of these bacteria. To overcome these problems and also for sustainable development of fisheries, it is important to develop novel strategies to control Aeromonas infections in fishes.

In recent years, application of nano-particle (NP) size compounds to treat bacterial infections (10) attracted the attention of aquaculturists all over the world. It is well recognized that silver (Ag) NPs possess potential antibacterial properties against a wide range of bacteria (11). Previously, in vitro studies suggested that AgNPs showed antimicrobial effects against fish pathogens such as Streptococcus iniae, Lactococcus garvieae, Yersinia ruckeri and Aeromonas hydrophila (12). However, studies pertaining to the antibacterial effects of AgNPs in vivo are not exploited. Though, AgNPs are promising bactericidal agents, Ag-induced toxicity limits the use of AgNPs. Previous studies indicated that AgNPs induces toxicity in fish embryos of zebra fish at a dose 
of $42 \mu \mathrm{g} / \mathrm{L}$ (13). Studies of Scown et al. (14) suggested that AgNPs 30nM size did not affect LPx levels whereas, AgNPs at a size of $10 \mathrm{nM}$ increased LPx levels in gills and liver rainbow trout fishes. Thus, it seems apparent that response of AgNPs differs with type of species and also size of NPs used. However, for effective therapeutic applicability of AgNPs in aquaculture, it is important to evaluate the precise mechanism(s) underlying antimicrobial effects of AgNPs in vivo. It is well established that during toxicity studies, stressors including bacteria primarily target energy metabolism which is of prime concern in fish physiology. Previously, it has been reported that A. hydrophila infection alters the levels of glucose and lactate levels in Catla catla during a 28-day exposure period (8). It has been also been claimed that decrease in metabolic scope negatively affects growth, reproduction and immune response and eventually decreases the efficiency of fish growth (15). On the other hand, AgNPs are claimed to regulate oxidative metabolism (14). So it is clear that A. hydrophila and AgNPs target oxidative metabolism through unknown mechanism(s). However, studies related to the effect of AgNPs on energy metabolism in A. hydrophila infected fishes are poorly understood. Energy metabolism is complex process which involves a range of enzymes and enzymes such as succinate dehydrogenase (SDH), glucose-6-phosphate dehydrogenase (G6PDH) and lactate dehyrogenase (LDH), which are believed to be important in the cascade of energy metabolism. Thus, alterations in these enzymes or their substrates reflect changes in energy metabolism which can also use as valuable indicators of stress factors including bacterial infections (16). Considering the facts that a) AgNPs inhibits A. hydrophila in vitro b) AgNPs and A. hydrophila both influence energy metabolic factors in fishes and c) till date no studies demonstrated the effect of AgNPs on energy metabolism in A. hydrophila infected fishes, the present study was aimed to evaluate the effect of AgNPs on the activity levels of SDH, G-6-PDH and LDH in selected tissues such as gills, liver and kidneys in $A$. hydrophila infected C. catla. We observed that AgNPs ameliorated metabolic fate of selected enzymes in $A$. hydrophila infected fishes and AgNPs mediated protective effects seems to be indirect.

\section{1.}

\section{Materials And Methods}

\section{Collection and maintenance of fishes}

Catla catla $(10.0 \pm 0.52 \mathrm{~cm}$ in length and $11.0 \pm 1.2 \mathrm{~g}$ in weight) were collected from A.P. Government Central Fish Farm, Kalyani dam, Chittoor Distrtict, AP, INDIA. All male fishes were maintained in cement aquaria (each 1,000 liters capacity), where they received un-chlorinated continuous gentle flow of water from a deeply sunk bore well within University campus. All the fishes were acclimated for at least two weeks and fed ad libitum fish diet in a laboratory conditions at the ambient, uncontrolled temperature of $28 \pm 2^{\circ} \mathrm{C}$ under the $12 \mathrm{~h}: 12 \mathrm{~h}$ light:dark conditions. The fish were starved $24 \mathrm{~h}$ prior to the start of the experiments in order to avoid metabolic variations due to diet, if any.

\subsection{Bacterial strain}

Bacterial strain, A. hydrophila was obtained from Microbial Type Culture Collection and Gene Bank (MTCC) Institute of Microbial Technology, Sector 39-A, Chandigarh, India. After obtaining bacteria, it was cultured in tryptone soya broth (Himedia) for $24 \mathrm{~h}$ at $37^{\circ} \mathrm{C}$. After incubation period, the culture was centrifuged at $800 \mathrm{~g}$ for $15 \mathrm{~min}$ at $4^{\circ} \mathrm{C}$. The packed cells were washed with phosphate buffered saline (PBS; pH 7.2) twice and then the required dose was prepared in PBS. The bacterial suspension was prepared to $1 \times 10^{9}$ Colony Forg Units as determined using a Neubauer haemocytometer. The selection of bacterial dose was based on earlier reports (6).

\subsection{Ag nano-particles}

Citrate coated Ag nanoparticles were kindly gifted from Head, Department of Soil Sciences, SV Agricultural College, Tirupati, AP, INDIA. The citrate coated Ag nanoparticles were prepared using chemical routes with an average size of $30 \mathrm{~nm}$. The measured zeta potentials of prepared Ag nanoparticles were formed to be $-42 \mathrm{mv}$. AgNPs stocks were prepared by suspending $100 \mathrm{mg}$ of citrate coated AgNPs in 1 litre millipore water and mixed well by sonicating for at least 30 minutes. After, sonication the dilutions were prepared as required.

\subsection{Experimental design}

\subsubsection{Selection of dose of AgNPs}

Fishes were randomly allocated into three groups with 20 each. Acute toxicity studies were designed over a period of 48 hours and 96 hours to evaluate the effect of AgNPs on changes in lipid peroxidation in fishes. Fishes in group 1 served as control fishes which were maintained on unchlorinated normal water. Fishes in groups 2 and 3 were treated as experimental fishes which were maintained in unchlorinated water containing $1 / 5^{\text {th }}$ and $1 / 10^{\text {th }}$ concentrations of $100 \mu \mathrm{g} / \mathrm{L}$. The dose selection was based on earlier reports (14). The quantity of silver in the selected concentrations was determined by atomic absorption spectroscopy available in Department of Soil Sciences, S.V. Agricultural College, Tirupati, AP, INDIA (data not shown). The appropriate dose of Ag 
anoparticles for further experiments was selected based on lipid peroxidation (LPx) assay, since this assay provides valuable information regarding the stress response of the test chemical.

\subsubsection{Bacterial Challenge Tests}

After selection of dose of Ag nanoparticles, the fishes were challenged with bacteria and the infected fishes were maintained in water containing Ag nanoparticles. This experiment demonstrates an animal system where the effect of Ag nanoparticles on A. hydrophila was observed in vivo. For the present study, fishes were randomly allocated into four groups consisting of 8 each. The experimental design is as follows:

Group 1: Fishes maintained in normal water served as controls

Group 2: Fishes were intramuscularly injected just below the dorsal fin with A. hydrophila $\left(1 \times 10^{9} \mathrm{CFU} / 50 \mu 1\right.$ of $0.85 \% \mathrm{NaCl}$ ). Disinfection was performed before injections using $70 \%$ ethanol and sterile and disposable insulin syringes were used for injection purposes. All the fishes were maintained for 14 days after post-injection.

Group 3: Fishes maintained in water containing 1/10 ${ }^{\text {th }}$ of $100 \mu \mathrm{g} / \mathrm{L}$ of $\mathrm{AgNPs}$ for a period of 14 days.

Group 4: Fishes received same experimental regimen as that of fishes in group and maintained in water containing $1 / 10^{\text {th }}$ of $100 \mu \mathrm{g} / \mathrm{L}$ of AgNPs for a period of 14 days. The AgNPs containing medium was changed at every $24 \mathrm{~h}$.

For the present study, 14 days experimental period was selected based on histological observations (author's unpublished data). Histological experiments revealed that organs such as gills, liver and kidneys were severely targeted by $A$. hydrophila at selected concentration in fishes. Hence these tissues were selected for the present study.

\subsection{Necropsy}

After completion of experimental period, fishes were sacrificed by cervical dislocation and gill, liver and kidneys were quickly isolated and placed in chilled box immediately and stored at $-20^{\circ} \mathrm{C}$ until further use.

\subsection{Lipid peroxidation assay}

The level of lipid peroxidation (LPx) was determined according the method described by Hiroshi et al. (17) with minor modifications. The level of LPx in the tissues was measured by a broken down product, malondialdehyde content by thiobarbituric acid reagent.

\subsection{Energy metabolism}

The isolated tissues were chopped with sterile scissors and homogenized $(10 \% \mathrm{~W} / \mathrm{V})$ in the required medium at $4{ }^{\circ} \mathrm{C}$ in an ice-jacketed glass homogenizer with a motor driven teflon-coated pestle. The homogenate was centrifuged at $700 \mathrm{~g}$ for $30 \mathrm{~min}$ at $4^{\circ} \mathrm{C}$ to remove nuclei and cell debris. The supernatant was collected and centrifuged at $16,000 \mathrm{rpm}$ for $1 \mathrm{~h}$ at $4^{\circ} \mathrm{C}$ to obtain mitochondrial and cytosolic fractions which were used for the study. The optimal assay conditions for individual enzymes were as follows:

\subsubsection{Succinate dehydrogenase (E.C: 1.3.99.1)}

Mitochondrial source was used for the SDH activity. The activity of SDH was assayed according to the method described by Nachlas et al. (18). Briefly, a reaction mixture $(2.0 \mathrm{ml})$ containing phosphate buffer $(100$ $\mu$ moles: pH 7.4), sodium succinate (40 $\mu$ moles: pH 7.4), and INT (2,4-Iodo phenyl-3-(4-nitrophenyl)-5-phenyl tetrazolium chloride; $2 \mu$ moles $)$ and enzyme source $(20 \mathrm{mg}$ ) prepared in $0.25 \mathrm{M}$ sucrose solution.

\subsubsection{Glucose-6-phosphate dehydrogenase (E.C: 1.1.1.49)}

G-6-PDH activity in the cytosolic fraction was assayed according to the method described by Bergmeyer and Bernt (19). Briefly, a reaction mixture $(2.0 \mathrm{ml})$ containing phosphate buffer $(100 \mu \mathrm{moles}: \mathrm{pH}$ 7.4), INT (4 $\mu$ moles), glucose-6-phosphate $(20 \mu \mathrm{moles})$, NADP $(0.1 \mu \mathrm{moles})$ and enzyme source $(20 \mathrm{mg})$ prepared in $0.25 \mathrm{M}$ sucrose solution.

\subsubsection{Lactate Dehydrogenase (E.C: 1.1.1.27)}

LDH activity was assayed in the cytosolic fraction was assayed according to the method described by Nachlas et al. (18). Briefly, a reaction mixture $(2.0 \mathrm{ml})$ containing phosphate buffer (100 $\mu$ moles: $\mathrm{pH} 7.4)$, sodium lactate $(20 \mu$ moles: pH 7.4), NAD $(0.1 \mu$ mole $)$ and INT $(2 \mu$ moles $)$ and enzyme source $(20 \mathrm{mg})$ prepared in $0.25 \mathrm{M}$ sucrose solution. The enzyme activities were measured at $37^{\circ} \mathrm{C}$ with appropriate enzyme and reagent blank using a spectrophotometer (Hitachi-U, Model No. 2001).

\subsection{Estimation of proteins}

The protein content in the enzyme source was estimated by the Lowry et al. (20) using Folin phenol reagent. The protein concentrations were determined by using bovine serum albumin as standard. 
Effect of silver nanoparticles on energy metabolism in selected tissues...

\section{9. $\quad$ Statistics}

The data were presented as mean \pm S.D. The statistical analysis of Data were performed using analysis of variance (one way ANOVA) followed by Dunnet's test. The differences were considered to be significant at

$p<0.01$. All statistical tests were performed using Statistical Package for Social Sciences (SPSS Inc., Chertsey, $\mathrm{UK})$.

\subsection{General toxicity}

\section{Results}

No mortality was observed in any of the controls and experimental groups. However, fishes injected with bacteria showed lethargic movements.

\subsection{Effect of $\mathbf{A g}$ nanoparticles on lipid peroxidation levels in selected tissues of fishes}

No significant changes in the LPx levels were observed in gills, liver and kidneys of fishes maintained in water containing $1 / 10^{\text {th }}$ concentrations of $100 \mu \mathrm{g} / \mathrm{l}$ of AgNPs as compared to control fishes (Table 1) over a period of $48 \mathrm{~h}$ or $96 \mathrm{~h}$. No significant changes were found in the LPx levels in liver and kidneys of fishes maintained in water containing $1 / 5^{\text {th }}$ concentrations of $100 \mu \mathrm{g} / \mathrm{l}$ of AgNPs as compared to unexposed fishes (Table 1) over a period of $48 \mathrm{~h}$ or $96 \mathrm{~h}$. However, a significant increase in LPx levels was observed in the gills of fishes exposed to $1 / 5^{\text {th }}$ concentrations of $100 \mu \mathrm{g} / \mathrm{l}$ of AgNPs over a period of $48 \mathrm{~h}$ (Table 1) and after $96 \mathrm{~h} \mathrm{LPx}$ levels in the gills were declined at the same concentration as compared to its respective control (Table 1). Hence for the present study, since no stress response was observed at $1 / 10^{\text {th }}$ concentrations of $100 \mu \mathrm{g} / \mathrm{l}$ of $\mathrm{AgNPs}$, further experiments were conducted by using this concentration.

\subsection{Effect of Ag nanoparticles on energy metabolism in A. hydrophila infected fishes}

Table 2 represent the changes in the activity levels of selected energy metabolic enzymes. Significant $(\mathrm{p}<0.001)$ decrease in the activity levels of SDH with a significant $(\mathrm{p}<0.01)$ increase in the activity levels of LDH and G6PDH in gills, liver and kidneys were observed in bacterial intoxicated fishes as compared to controls (Table 2). However, a significant $(\mathrm{p}<0.01)$ increase in the activity levels of SDH with a significant $(\mathrm{p}<0.01)$ decrease in the activity levels of LDH and G6PDH in gills, liver and kidneys were observed in bacterial intoxicated fishes exposed to Ag nanoparticles as compared to bacterial intoxicated fishes (Table 2). No significant changes were observed in the activity levels of SDH, LDH and G6PDH were observed in selected tissues of Ag nanoparticles exposed fishes as compared to controls.

\section{Discussion}

Though AgNPs are believed to possess bactericidal properties against fish pathogens in vitro (12), many in vivo studies demonstrated conflicting results against use of AgNPs in fishes $(13,14)$. Therefore, the purpose of the present study was twofold. Firstly, to select appropriate dose of AgNPs that could not induce any stress response in fishes (see section 2.4.1) and secondly to evaluate the effect of AgNPs on energy metabolism in A. hydrophila intoxicated fishes (see section 2.4.2). The results of the present study were the first to demonstrate that AgNPs-induced ameliorative effects on energy metabolism could be indirect and probably through their antibacterial properties in A. hydrophila infected fishes. In the current study, the rationale for choosing LPx as an index for selection of appropriate dose was based on the fact that LPx is a well known indicator of stress response against a range of chemical compounds including Ag. Furthermore, the establishment of selection of appropriate dose of AgNPs for its therapeutic utility is considered very important since; some reports indicated the toxic effects of $\mathrm{Ag}$ nanoparticles in fishes (13). The results of the present study suggested that acute exposure of fishes (48h and 96h) to AgNPs at $1 / 10^{\text {th }}$ concentration of $100 \mu \mathrm{g} / \mathrm{L}$ did not affect LPx levels in gills, liver and kidney of fishes. On the other hand, when fishes were exposed to $1 / 5^{\text {th }}$ concentration of $100 \mu \mathrm{g} / \mathrm{L}$ AgNPs, LPx levels were enhanced in gills of fishes over $48 \mathrm{~h}$ as compared to controls. However, at the same concentration, the LPx levels in the gills of fishes after 96h were declined to its respective control. Earlier studies suggested that exposure of fishes to $\mathrm{N}_{10}$ particles was found to induce expression of cytochrome P450 monooxygenase system (cypla2) in the gills, suggesting a possible increase in oxidative metabolism in this tissue (14). It has also been suggested that gill tissue have ability to modulate up regulation of several genes associated with DNA repair mechanisms during stress conditions (21). Further, the endogenous antioxidant system has ability to mitigate generation of free radicals. Thus, the reduced LPx levels after 96h in the gills of fishes exposed to $1 / 5^{\text {th }}$ concentration of $100 \mu \mathrm{g} / \mathrm{L}$ AgNPs might be due to up regulation of oxidative metabolic genes and also intrinsic antioxidant mechanisms. On the other hand, no significant change in LPx levels in the selected tissues of fishes exposed to $1 / 10^{\text {th }}$ concentration of $100 \mu \mathrm{g} / \mathrm{L}$ AgNPs might indicate a counter active mechanism of intrinsic antioxidant system. Though, antioxidant enzymes were not determined in the present study, it is well known that antioxidant enzymes play an important role during alterations in pro- 
oxidant and/or redox changes (22). One of the important findings of the present study (see section 2.4.2) suggests that $1 / 10^{\text {th }}$ concentration of $100 \mu \mathrm{g} / \mathrm{L}$ AgNPs reversed the changes induced by A. hydrophila on activity

levels of oxidative enzymes in the selected tissues of fishes. It is well known that energy metabolism plays an important role in the animal's physiology. The enzymes such as SDH, G6PDH and LDH were selected because they are representatives of aerobic respiration, hexose monophospahe shunt pathway and anaerobic respiration, respectively and which inevitably control energy metabolism (23). In the present study, A. hydrophila intoxication significantly reduced the activity levels of SDH with a significant increase in the activity levels of G6PDH and LDH levels in gills, liver and kidneys of fishes over a period of 14 days. From the results it is evident that during A. hydrophila intoxication shifting of aerobic respiration (decreased activity levels of SDH) to anaerobic respiration (increased activity levels of LDH) occurs in gills, liver and kidneys of fishes, which indicates energy crisis in the tissues. In the present study, significant increase in the activity levels of G6PDH indicate enhanced operation of HMP pathway to meet the needs of energy crisis in gills, liver and kidney of $A$. hydrophila intoxicated fishes. These results also demonstrated that A. hydrophila intoxication induced alterations in the oxidative enzymes might be an adaptive mechanism to compensate energy demands in fishes. Earlier histological experiments from our laboratory suggests that A. hydrophila intoxication causes deterioration of structural architecture of gills, liver and kidneys of fishes which might eventually leads to changes in activity levels of energy metabolic enzymes (data not shown). In consistent with our results earlier studies of Kaleeswaran et al. (8) also suggested that A. hydrophila infection deteriorates structural architecture of spleen in Catla catla. The same author's also demonstrated that A. hydrophila intoxication alters biochemical variables including serum glucose levels in Catla catla which plays an important role in cellular respiration (8). In addition, it has also been suggested that injection of heat inactivated A. hydrophila significantly increased the expression levels of LDH in the spleen of Catla catla (9), which consequently reflects switching of anaerobic respiration. On the other hand, exposure of bacterial infected fishes to AgNPs showed a reversal changes in the activity levels of oxidative enzymes in the selected tissues, indicating protective effects of AgNPs against bacteria.

Notwithstanding, the exact mechanism of AgNPs induced-reversal effects on oxidative enzymes in selected tissues of bacterial infected fishes is not clear, we speculate that the protective effects of AgNPs are indirect since no significant changes were observed in the activity levels of SDH, G6PDH and LDH in fishes exposed to AgNPs alone as compared to unexposed controls and probably associated with its bactericidal properties. The results are in consonance with earlier reports (Scown et al., 2010). It is fact that currently no studies provide the interactions between AgNPs and bacteria in vivo, however in vitro experiments have demonstrated some plausible mechanisms. Piecing the mechanisms of AgNPs-induced antibacterial properties obtained from in vitro studies, it can be hypothesized that a) positively charged silver particles binds with negatively charged bacterial membrane by strong electrostatic attractions (24) b) Ag particles after binding with cell membrane accumulates and causes pits on cell membrane thereby increases permeability which eventually leads to release of lipopolysaccharides and membrane proteins (25) and c) Ag nanoparticles target and damage cell membrane of bacteria through generation of free radicals and finally leads to cell death (26). Finally, we conclude that AgNPs at $1 / 10^{\text {th }}$ concentration of $100 \mu \mathrm{g} / \mathrm{L}$ did not elicit any stress response and exhibits antibacterial properties in vivo as evidenced by reversal of activity levels of oxidative enzymes in the gills, liver and kidney of $A$. hydrophila injected fishes.

\section{Conclusion}

In view of future perspectives, we made an attempt to address the therapeutic utility of AgNPs against bacterial infections in vivo. This provides the first evidence that A. hydrophila infection at least in part targets oxidative metabolism and it could seriously compromise fish health. Our results also indicated that AgNPs through their bactericidal properties mitigate A. hydrophila-induced changes in oxidative enzymes of selected tissues in Catla catla. However, for usage of AgNPs as therapeutic candidates in aquaculture further studies are warranted. Thus, it is hoped that, further research in the fish model developed will strengthen and expand the knowledge on AgNPs and its cross-talk with fish physiology during diseased conditions. Ultimately, studies in this direction could help to shape the future of aquaculture.

\section{Acknowledgements}

The authors thank Head, Department of Aquaculture, S. V. University, Tirupati-517 502 and Head, Department of Soil Sciences, S.V. Agricultural College Tirupati-517 502, AP, India for providing laboratory facilities and silver nanoparticles, respectively. The authors also thank University Grants Commission, New Delhi, India for the financial support towards the research work. 


\section{References}

[1]. K. Anjani, P.K. Joshi and S.B. Pratap, Fisheries Sector in India: An Overview of Performance, Policies and Programmes, in K. Anjani, K.K. Pradeep and P.K. Joshi (Eds.), A Profile of People, Technologies and Policies in Fisheries Sector in India, (2003) $1-16$.

[2]. S. Ayyappan, and J.K. Jena, Grow-out production of carps in India, Journal of Applied Aquaculture 13(3/4), 2003, 251-282.

[3]. B. Mohanty, S. Mohanty, J. Sahoo and A. Sharma, Climate Change: Impacts on Fisheries and Aquaculture, in S. Simard (Ed.), Climate Change and Variability, (Europe: Sciyo, Intech, 2010) 1-486.

[4]. M. J. A. Sarkar and M. M. Rashid, Pathogenicity of the bacterial isolate Aeromonas hydrophila to catfishes, carps and perch, Journal of Bangladesh Agricultural University 10(1), 2012, 157-161.

[5]. J.L. Torres, M. Sharif and A.T. Law, Identification and virulence screening of Aeromonas spp. isolated from healthy and epizootic ulcerative syndrome (EUS) infected fish, in R. Hirano, and I. Hanyu (Eds.), Proceedings of the Second Asian Fisheries Forum, (Asian Fisheries Society, Manila, Philippine, 1996) pp. 663-668.

[6]. H.A.C.C. Perera, and A. Pathiratne, Enhancement of immune responses in Indian carp, Catla catla, following adistration of levamisole by immersion, in M.G. Bondad-Reantaso, C.V. Mohan, M. Crumlish, and R.P. Subasinghe, (Eds.), Diseases in Asian Aquaculture VI. Fish Health Section, (Asian Fisheries Society, Manila, Philippines, 2008) pp 505.

[7]. B. Xavier Innocent, M. Syed Ali fathima and D. Dhanalakshmi, Studies on the immouostimulant activity of Coriandrum sativum and resistance to Aeromonas hydrophila in Catla catla, Journal of Applied Pharmaceutical Science 1 (07), 2011, 132-135.

[8]. B. Kaleeswaran, S. Ilavenil, S. Ravikumar, Changes in biochemical, histological and specific immune parameters in Catla catla (Ham.) by Cynodon dactylon (L.), Journal of King Saud University - Science 24, 2012, 139-152

[9]. B. Kaleeswaran, S. Ilavenil, S. Ravikumar, Enhancement of specific immune response in Catla catla (Ham.) Against Aeromonas hydrophila by the extract of Cynodon dactylon (L.), Hitek Journal of Biological Sciences and Bioengineering 1 (1), $2012,1-15$.

[10]. T. Vandevelde, H. Renner, G. Schlamp, Silver, silver compounds, and silver alloys. Ullmann's Encylopedia of Industrial Chemistry. chapter 10. (New York, NY, USA: John Wiley \& Sons, 2009)

[11]. J.S. Kim, E. Kuk, K.N. Yu, J.H. Kim, S.J. Park, H.I.Lee, S.H. Kim, S.J. Park, Y.H. Park, C.Y. Hwang, Y.K. Kim, Y.S. Lee, D.H. Jeong, M.H. Cho, Antimicrobial effects of silver nanopaticles. Nanomedicine: Nanotechnology Biology and Medicine. 3, 2007, 95-101.

[12]. M. Soltani, M. Ghodratnema, H. Ahari, H.A. Ebrahimzadeh Mousavi, M. Atee, F. Dastmalchi, J. Rahmanya, The inhibitory effect of silver nanoparticles on the bacterial fish pathogens Streptococcus iniae Lactococcus garvieae Yersinia ruckeri Aeromonas hydrophila, International Journal of Veterinary Research 3,2009, 137-142.

[13]. B. Lee, C. N. Duong, J. Cho, J. Lee, K. Kim, Y. Seo, P. Kim, K. Choi, and J. Yoon, Toxicity of Citrate-Capped Silver Nanoparticles in Common Carp (Cyprinus carpio), Journal of Biomedicine and Biotechnology, 2012 (doi:10.1155/2012/262670) T.M. Scown, E.M. Santos, B.D. Johnston, B. Gaiser, M. Baalousha S. Mitov, J.R. Lead, V. Stone, T.F. Fernandes, M. Jepson et al., Effects of aqueous exposure to silver nanoparticles of different sizes in rainbow trout. Toxicological Sciences 115, 2010, 521-534.

[15]. M. A. Jones, M. D. Powell, J. A. Becker, and C. G. Carter, Effect of an acute necrotic bacterial gill infection and feed deprivation on the metabolic rate of Atlantic salmon Salmo salar, Disease of Aquatic Organisms 78, 2007, $29-36$.

E.P. Dahlhoff, (2004) Biochemical indicators of stress and metabolism applications

a. for marine ecological studies. Annual Reviews of Physiology 66, 2004, 1-25.

[17]. O. Hiroshi, N. Ohisi and K. Yagi, Assay for lipid peroxides in animal tissues by TBA reaction. Analytical Biochemistry 95, 1979,351-358.

[18]. M.M. Nachlas, S.I. Margulies and, A.M. Seligman, A colorimetric method for the estimation of succinate dehydrogenase. Journal of Biological Chemistry 235, 1960, 499-505.

[19]. H.U. Bergmeyer and E. Bernt, Methods of Enzymatic Analysis, in H.U. Bergmeyer (Ed.), (Academic Press, New York, 1965)

[20]. H. Lowry, N.I. Rosebrough, A.L. Far and R.J. Randall, 1951. Protein measurement with folin phenol reagent, Journal of Biological Chemistry 193, 1951, 265-275.

[21]. A.M. Diehl, Cytokine regulation of liver injury and repair. Immunological Reviews 174, $2000,160-171$.

[22]. M. Sevcikova, H. Modra, A. Slaninova, Z. Svobodova Metals as a cause of oxidative stress in fish: a review, Veterinarni Medicina 56, 2011, 537-546.

[23]. H.A. Harper, V.W. Rodwell and P.A. Mayes, (1979) in: Review of physiological chemistry, (17 ${ }^{\text {th }}$ edition, Lange Medical Publications, California, 1979)

[24]. T. Hamouda, A. Myc, B. Donovan, A. Shih, J.D. Reuter, Jr. J.R. Baker, A novel surfactant nanoemulsion with a unique nonirritant topical antimicrobial activity against bacteria, enveloped viruses and fungi, Microbiological Research 156, $2000,1-7$.

[25]. I. Sondi and B. Salopek-Sondi, Silver nanoparticles as antimicrobial agent: a case study on E. coli as a model for Gram-negative bacteria, Journal of Colloidal Interface Sciences 275, 2004, 177-182.

[26]. M. Danilczuk, A. Lund, J. Saldo, H. Yamada and J. Michalik, Conduction electron spin resonance of small silver particles, Spectrochimaca Acta Part A 63, 2006, 189-191.

Table 1: Effect of silver nanoparticles (AgNPs) on lipid peroxidation ( $\mu$ moles of malondialdehyde formed/g wet wt. of tissue) levels in selected tissues of Indian major carp, Catla catla

\begin{tabular}{lllllll}
\hline Time & $48 \mathrm{~h}$ & \multicolumn{2}{l}{$96 \mathrm{~h}$} \\
\hline Tissue & Control & \multicolumn{2}{l}{ AgNPs $(100 \mu \mathrm{g} / \mathrm{L})$ exposed } & Control & \multicolumn{2}{l}{ AgNPs $(100 \mu \mathrm{g} / \mathrm{L})$ exposed } \\
\cline { 3 - 4 } \cline { 6 - 7 } & & $1 / 5^{\text {th }}$ & $1 / 10^{\text {th }}$ & & $1 / 5^{\text {th }}$ & $1 / 10^{\text {th }}$ \\
\hline Gills & $3.51^{\mathrm{a}} \pm 0.72$ & $6.41^{\mathrm{b}} \pm 0.54$ & $3.83^{\mathrm{a}} \pm 0.49$ & $3.91^{\mathrm{a}} \pm 0.43$ & $4.92^{\mathrm{c}} \pm 0.41$ & $3.75^{\mathrm{a}} \pm 0.81$ \\
Liver & $4.23^{\mathrm{a}} \pm 0.56$ & $4.71^{\mathrm{a}} \pm 0.36$ & $4.41^{\mathrm{a}} \pm 0.74$ & $4.27^{\mathrm{a}} \pm 0.54$ & $4.54^{\mathrm{a}} \pm 0.74$ & $4.28^{\mathrm{a}} \pm 0.75$ \\
Kidney & $3.84^{\mathrm{a}} \pm 0.42$ & $4.18^{\mathrm{a}} \pm 0.62$ & $4.08^{\mathrm{a}} \pm 0.35$ & $4.17^{\mathrm{a}} \pm 0.38$ & $4.21^{\mathrm{a}} \pm 0.91$ & $4.15^{\mathrm{a}} \pm 0.69$ \\
\hline
\end{tabular}

Values are mean \pm S.D. of 10 individual fishes.

Mean values with different letters in a row differ significantly from each other at $\mathrm{p}<0.01$. 
Table 2: $\quad$ Effect of $1 / 10^{\text {th }}$ concentration of silver nanoparticles (AgNPs; $100 \mu \mathrm{g} / \mathrm{L}$ ) on activity levels of selected biochemical enzymes in selected tissues of A. hydrophila injected Indian major carp,

\section{Catla catla}

\begin{tabular}{|c|c|c|c|c|}
\hline \multirow[b]{2}{*}{ Tissue } & \multirow[b]{2}{*}{ Groups } & \multicolumn{3}{|l|}{ Enzyme } \\
\hline & & SDH & LDH & G6PDH \\
\hline \multirow[t]{4}{*}{ Gills } & Control & $0.638^{\mathrm{a}} \pm 0.015$ & $0.072^{\mathrm{a}} \pm 0.014$ & $0.175^{\mathrm{a}} \pm 0.021$ \\
\hline & AH infected & $0.412^{\mathrm{b}} \pm 0.025$ & $0.143^{b} \pm 0.021$ & $0.245^{\mathrm{b}} \pm 0.031$ \\
\hline & AgNPs exposed & $0.641^{\mathrm{a}} \pm 0.027$ & $0.079^{\mathrm{a}} \pm 0.018$ & $0.168^{\mathrm{a}} \pm 0.041$ \\
\hline & $\begin{array}{l}\text { AH infected }+ \\
\text { AgNPs exposed }\end{array}$ & $0.502^{\mathrm{c}} \pm 0.019$ & $0.113^{\mathrm{c}} \pm 0.012$ & $0.211^{\mathrm{c}} \pm 0.027$ \\
\hline \multirow[t]{4}{*}{ Liver } & Control & $0.873^{\mathrm{a}} \pm 0.042$ & $0.318^{\mathrm{a}} \pm 0.019$ & $0.784^{\mathrm{a}} \pm 0.042$ \\
\hline & AH infected & $0.642^{\mathrm{b}} \pm 0.024$ & $0.438^{\mathrm{b}} \pm 0.021$ & $0.862^{\mathrm{b}} \pm 0.029$ \\
\hline & AgNPs exposed & $0.867^{\mathrm{a}} \pm 0.039$ & $0.324^{\mathrm{a}} \pm 0.035$ & $0.792^{\mathrm{a}} \pm 0.034$ \\
\hline & $\begin{array}{l}\text { AH infected + } \\
\text { AgNPs exposed }\end{array}$ & $0.712^{\mathrm{c}} \pm 0.037$ & $0.384^{c} \pm 0.018$ & $0.813^{\mathrm{c}} \pm 0.019$ \\
\hline \multirow[t]{4}{*}{ Kidney } & Control & $0.798^{\mathrm{a}} \pm 0.038$ & $0.284^{\mathrm{a}} \pm 0.021$ & $0.514^{\mathrm{a}} \pm 0.027$ \\
\hline & AH infected & $0.584^{b} \pm 0.041$ & $0.349^{\mathrm{b}} \pm 0.017$ & $0.743^{b} \pm 0.033$ \\
\hline & AgNPs exposed & $0.781^{\mathrm{a}} \pm 0.038$ & $0.276^{\mathrm{a}} \pm 0.033$ & $0.527^{\mathrm{a}} \pm 0.037$ \\
\hline & $\begin{array}{l}\text { AH infected }+ \\
\text { AgNPs exposed }\end{array}$ & $0.658^{\mathrm{c}} \pm 0.027$ & $0.302^{\mathrm{c}} \pm 0.026$ & $0.642^{\mathrm{c}} \pm 0.047$ \\
\hline
\end{tabular}

Values are mean \pm S.D. of 10 individual fishes.

Units: $\mu$ moles of formazan formed/mg protein $/ \mathrm{h}$.

Mean values with different letters in a column differ significantly from each other at $\mathrm{p}<0.01$.

For evaluation of statistical analysis, for all experimental groups, fishes in control group served as control. 